\title{
PHYTOCHEMICAL COMPOUNDS AND ANTIOXIDANT ACTIVITY OF SOME LENTIL GENOTYPES GROWN IN EGYPT
}

\author{
A.S. Abd El-Sattar \\ Food Technology Research Institute, Agric. Research Center, Egypt \\ Received: Feb. 20, $2018 \quad$ Accepted: Mar. 1, 2018
}

\begin{abstract}
The present study was carried out to compare and evaluate different varieties of Lentil seeds grown in Egypt for selecting the high quality varieties. The obtained results revealed that, lentil variety Giza 51 contains the highest crud protein content $25.55 \%$ followed by variety Sinai 1 which recorded $24.83 \%$ while the lowest value of crud protein was $23.10 \%$ for variety Giza 29 . potassium is the major element among all of the determined minerals content, Sinai1 had the highest potassium $420 \mathrm{mg} / 100 \mathrm{~g}$ for all samples, Furthermore, Giza 370 contain the highest content of iron $11.30 \mathrm{mg} / 100 \mathrm{~g}$. Giza 51 variety had the highest content of total polyphenols which was 720 mg GAE /100g followed by variety Sinai 1 which $710 \mathrm{mg}$ GAE /100g. In addition, Giza 51 variety presented the highest DPPH scavenging activity $63.50 \%$, followed by Sinai $162.42 \%$, while Giza 9 contain the highest content of folate which was 196. $\mu \mathrm{g} / 100 \mathrm{~g}$ followed by Sinai 1 which recorded $193.0 \mu \mathrm{g} / 100 \mathrm{~g}$. On the other hand, the phytic acid, content of the different lentil seed varieties were ranged from 0.49 to $0.56 \%$. Furthermore, (H.C.A.) ranged from $106.70 \%$ for Giza 29 to $118.80 \%$ for Sinai 1. However, Giza 9 had the highest cookebility which was 96.50\% followed by Sinai 1 which recorded $91.70 \%$.
\end{abstract}

Key words: Lentil - Phytochemical compounds - Cooking quality.

\section{INTRODUCTION}

Lentil (Lens culinaris) is an ancient crop of classical Mediterranean civilization and continues to play an important role in human health (Zohary and Hopf 2000). Legumes such as beans, chickpeas and lentils, are seen as staple foods and they are nutritious and improve health known as the 'meat of the poor people. Because of their high protein content, beans are now presented as a staple food for vegetarians and for people affected by nutrition related health problems, such as diabetes, obesity, and over-weight (Leterme and Munoz 2002). Lentil (Lens culinaris Medikus) is excellent source of proteins, carbohydrates and dietary fibers. Besides, legume flours provide many essential amino acids, vitamins, minerals, oligosaccharides and phenol compounds (Roy et al., 2010). However, antinutritional factors such as phytic acid, trypsin inhibitors and tannins, which are present in lentil was considered undesirable for obstructing the bioavailability of minerals (Wang and Daun 2006) and they compromise the protein digestibility, reducing the nutritional value of this food (Rathod and Annapure (2016). Therefore, it must be substantial reduction or complete elimination of these antinutrients before they can be safely consumed. The effects of processing on antinutritional factors vary notably, depending on the techniques and conditions, including time, temperature and moisture content, which in turn can enhance the bioavailability of proteins and minerals (Alonso, et al., 2000). Lentil seeds have high levels of iron, potassium, folate, and niacin and are often recommended for vegetarians who need to supplement their diet with additional iron and protein. (Chung, et al., 2008). Lentils possessed the highest concentrations of phenolic contents and antioxidant activity, and the higher 
antioxidant activity was strongly correlated with the phenolic contents (Xu and Chang 2007). Dietary antioxidants may play an important role in protecting the cell against damage caused by free radicals. Consumption of foods containing antioxidants may prevent some diseases and therefore, it is very important to determine their antioxidant capacity in order to estimate the repercussion on oxidative stress in living beings (Doblado et al., 2007) .

Also, lentil seeds are bioactive dietary supplements and as an antioxidant protect the human body from free radicals as well as retard the progress of many chronic diseases including hypertension, diabetes mellitus, cardiovascular diseases and cancer (Ford et al., 2007).

The present study was carried out to compare and evaluate some varieties of Lentil grown in Egypt for selecting the highest quality varieties.

\section{MATERIALS AND METHODS Materials:}

Five Lentil seeds varieties namely Giza 9, Giza 29, Giza 51, Giza 370 and Sinai 1 were obtained from fields crops Research Institute, Agric. Research Center, Ministry of Agric. Giza. Egypt.

\section{Preparation of lentil samples:}

Lentil seeds varieties were cleaned and divided into two parts the first one was used as Lentil seeds, where the second was milled to obtained the Lentil flours. The Lentil seeds and flours were kept in polyethylene bags and stored in freezer at $-18^{\circ} \mathrm{C}$ until further analysis.

\section{Proximate chemical composition of lentil seeds:}

Moisture, ash, crude protein content ( $N$ $x$ 6.25) and crude fat of the samples were determined according to the method described in A. O. A. C. (2005). Total carbohydrates content was calculated by difference as follows: Total carbohydrates $\%=100-$ (crude protein $\%$ + ether extract $\%+$ ash $\%$ ) on dry weight basis.

Determination of minerals content:

The sample was digested using concentrated $\mathrm{HNO} 3$ for 2 hrs (till the solution become colorless) and diluted to $100 \mathrm{ml}$ with distilled water. Calcium, manganese, magnesium, iron, zinc and copper contents of lentil samples were determined using the atomic absorption spectrophotometer Perken Elmer Model 20180 following the method of Pearson (1976). Potassium and sodium contents of lentil samples were estimated using flame photometer as given by Pearson (1976). On the other hand, phosphorus was determined colorimetrically using ascorbic acid method as described by Murphy and Riley (1962).

\section{Determination of phytochemical compounds :}

\section{Extraction of total phenolic} compounds:

Total phenolic compounds were extracted according to the method described by Fernandez-Orozco et al. (2009). Flour of lentil seeds were subjected to phenolics extraction using methanol 95\%. The extraction process was continued for $24 \mathrm{~h}$ at room temperature by stirring the flours in the solvent. The extracts were centrifuged at $4000 \mathrm{rpm}$ for $15 \mathrm{~min}$ and filtered through filter paper (Whatman No. 41). The solvent was removed from the extracts using a rotary evaporator at $40^{\circ} \mathrm{C}$ under vacuum. The extracts were further dried using vacuum oven at $40^{\circ} \mathrm{C}$ and then kept in dry clean closed black glass bottle at $4^{\circ} \mathrm{C}$ for further analysis

\section{Determination of total phenolic :}

Total phenol compounds content was determined according to (Gutfinger, 1981). The method is based on the colour 
reaction of Folin-Ciocalteu reagent with hydroxyl groups. Reaction absorbance was measured at $760 \mathrm{~nm}$ using a spectrophotometer. The results were expressed as $\mathrm{mg}$ gallic acid per $100 \mathrm{~g}$ of extract.

\section{Antioxidant activity (DPPH) assay: Antioxidant activity was measured using the DPPH (2,2-diphenyl-1- picrylhydrazyl) method described by Soler-Rivas, et al. (2000). Folate contents was determined according to the method of A. O. A. C. (2005).}

\section{Determination of antinutritional factors:}

1- Phytic acid was measured using the method described by Fruehbeck et al., (1995).

2- Tannins in the methanol extracts were measured according to the vanillin method of Price et al., (1978).

3- Trypsin inhibitor was analyzed as described by Kakade et al., (1974).

\section{Determination of Cooking quality of lentil seed :}

A- Hydration coefficient of seeds before cooking (H.C.B. \%) $10 \mathrm{~g}$ dry seeds from each experimental varieties were soaked in tap water for $8 \mathrm{hr}$. at $25^{\circ} \mathrm{c}$ then was calculated as

(H.C.B. \%) = $\frac{\text { weight of soaked seeds-weight of dry seeds }}{\text { weight of dry seeds }} \times 100$.

B - Hydration coefficient of seeds after cooking (H.C.A. \%) was calculated by placing $10 \mathrm{~g}$ of dry seeds from each experimental varieties in placed glass tube $100 \mathrm{~cm}$ containing enough water . the tubes were put in oven for $2 \mathrm{hr}$. at $100 \mathrm{c}$ the Hydration coefficient of seeds after cooking (H.C.A.) was determined in cooked seeds according to the method of Selim, (2000) as follows

(H.C.A. \%) =

$$
\frac{\text { weight of cooked seeds-weight of dry seeds }}{\text { weight of dry seeds }} \times 100 \text {. }
$$

C- The total soluble solids (T.S.S. \%) was determined in Hydration coefficient of seeds after cooking (H.C.A. \%) above by drying at $60 \mathrm{c}$ over night . (T.S.S. \%) was calculated as Selim, (2000) .

(T.S.S. \%) $=$

$\frac{\text { (weight drying - weight of empty pot }}{\text { initial weight }} \times 100$.

D - The Seed cookebility\% of lentil seeds was measured by using the normal press of fingers and comparing between the cooked seeds for their hardness, which means the maximum force throughout their test. This cooking test was made according to the method described by Selim, (2000).

\section{Statistical analysis:}

Most of the received data were analyzed statistically using the analysis of variance and the means were further tested using the least significant difference test (LSD) as outlined by Steel and Torrie (1980).

\section{RESULTS AND DISCUSSION}

Proximate chemical composition of different lentil seed varieties :

The chemical composition of five lentil seed varieties were determined and the results are recorded in Table (1). The moisture content of the five lentil seed varieties were ranged from 9.03 to $11.23 \%$. However, lentil variety Giza 51 contains the highest content of crud protein $25.55 \%$ followed by lentil variety Sinai $124.83 \%$ while the lowest value of crud protein was $23.10 \%$ for lentil variety Giza 29 . These results are in line with those (Barbana and Boye 2011 and Rathod and Annapure 2016). They reported that, protein content can range from 20.6 to $31.4(\mathrm{~g} / 100 \mathrm{~g})$ depending on lentil cultivar and soil or climate characteristics. Apparent also from the same table that, lentil seed varieties contain from 1.55 to $1.97 \%$ crud fat, 2.27 to $2.70 \%$ ash content, and 70.02 
to 72 . $80 \%$ total carbohydrate. These results are in line with those (Ghavidel and Prakash, 2007 ; Dilis and Trichopoulou 2009; Silva-Cristobal et al., 2010; Karaca et al. , 2011 and Ma et al., 2011) . Furthermore, chemical composition of lentil is generally affected by environmental and genetic factors Eyaru, et al., (2009) .

\section{Minerals content of different lentil varieties:}

Minerals or elements play an important role in human nutrition, some are essential for much component as hem for blood. magnesium and manganese for the activation of some enzymes and stimulation insuline activity, calcium and phosphorus are essential for bones. Potassium is very important for cardiovascular diseases. (National Academy of Sciences, 2001). Minerals content of five lentil varieties were determined and the data were recorded in Table (2). The results indicate that potassium is the major element among all of the determined mineral contents. In addition, Giza 370 had the highest potassium compared to the other samples that recorded $955 \mathrm{mg} \mathrm{k/100g}$, followed by Giza 51940 mg k/100g. while, the lowest potassium content was $890 \mathrm{mg} \mathrm{k} / 100 \mathrm{~g}$ for Giza9 .

Table (1): Gross chemical composition of different lentil varieties .

\begin{tabular}{||c||c||c|c||c||c||}
\hline \hline $\begin{array}{l}\text { lentil } \\
\text { Varieties }\end{array}$ & Moisture\% & Protein\% & fat\% & Ash\% & $\begin{array}{c}\text { Total } \\
\text { carbohydrates\%** }\end{array}$ \\
\hline \hline Giza 9 & ${ }^{*} 10.68 \mathrm{~b}$ & ${ }^{*} 24.40 \mathrm{~b}$ & ${ }^{*} 1.97 \mathrm{a}$ & ${ }^{*} 2.38 \mathrm{ab}$ & $* 71.25 \mathrm{c}$ \\
\hline \hline Giza 29 & $9.03 \mathrm{~d}$ & $23.10 \mathrm{~d}$ & $1.83 \mathrm{ab}$ & $2.27 \mathrm{~b}$ & $72.80 \mathrm{a}$ \\
\hline \hline Giza 51 & $11.23 \mathrm{a}$ & $25.55 \mathrm{a}$ & $1.73 \mathrm{~b}$ & $2.70 \mathrm{a}$ & $70.02 \mathrm{~d}$ \\
\hline \hline Giza 370 & $11.00 \mathrm{ab}$ & $23.70 \mathrm{c}$ & $1.67 \mathrm{~b}$ & $2.40 \mathrm{ab}$ & $72.23 \mathrm{~b}$ \\
\hline Sinai 1 & $9.26 \mathrm{c}$ & $24.83 \mathrm{ab}$ & $1.55 \mathrm{c}$ & $2.31 \mathrm{~b}$ & $71.32 \mathrm{c}$ \\
\hline
\end{tabular}

* Each value is an average of three determinations.

+ Values followed by the same letter in Column are not significantly different at $P \leq 0.05$

**Total carbohydrates was calculated by difference.

Table (2): Mineral contents (mg/100g) of different lentil varieties (on dry weight basis).

\begin{tabular}{|c|c|c|c|c|c|}
\hline $\begin{array}{c}\text { samples } \\
\text { Mineral } \\
\text { Elements }\end{array}$ & Giza 9 & Giza 29 & Giza 51 & Giza 370 & Sinai 1 \\
\hline $\mathrm{P}$ & $410 \mathrm{ab}$ & $400 \mathrm{~b}$ & $380 \mathrm{c}$ & $350 \mathrm{~d}$ & $420 \mathrm{a}$ \\
\hline $\mathrm{Na}$ & $11.22 \mathrm{~b}$ & $8.90 \mathrm{e}$ & $10.10 \mathrm{c}$ & $12.10 \mathrm{a}$ & $9.50 \mathrm{~d}$ \\
\hline $\mathrm{K}$ & $890 \mathrm{e}$ & $900 \mathrm{~d}$ & $940 \mathrm{~b}$ & $955 \mathrm{a}$ & $920 \mathrm{c}$ \\
\hline $\mathrm{Ca}$ & $71 \mathrm{ab}$ & $59 \mathrm{~d}$ & $69 \mathrm{~b}$ & $75 \mathrm{a}$ & $65 \mathrm{c}$ \\
\hline $\mathrm{Mg}$ & $115 \mathrm{~b}$ & $112 \mathrm{c}$ & $110 \mathrm{c}$ & $100 \mathrm{~d}$ & $121 \mathrm{a}$ \\
\hline $\mathrm{Fe}$ & $11.0 \mathrm{a}$ & $8.90 \mathrm{c}$ & $10.50 \mathrm{~b}$ & $11.30 \mathrm{a}$ & $9.2 \mathrm{c}$ \\
\hline $\mathrm{Zn}$ & $3.60 \mathrm{~b}$ & $3.10 \mathrm{c}$ & $3.50 \mathrm{~b}$ & $2.70 \mathrm{~d}$ & $3.9 \mathrm{a}$ \\
\hline
\end{tabular}

* Each value is an average of three determinations.

+ Values followed by the same letter in row are not significantly different at $P \leq 0.05$ 
However, the data in the same table revealed that, Giza 370 contain the highest content of iron which was $11.30 \mathrm{mg}$ fe l100g followed by Giza 9 which recorded $11.0 \mathrm{mg}$ fe $/ 100 \mathrm{~g}$. while the lowest value of iron was $(9.2 \mathrm{mg}$ fe $/ 100 \mathrm{~g}$ ) for Sinai 1. The iron is important for the schoolchildren, which mostly needs more iron to avoid the anemia especially in developing countries. The results indicated that lentil varieties are a good source for the minerals. Furthermore, Sinai1 contain the highest content of magnesium which was $121.0 \mathrm{mg} / 100 \mathrm{~g}$ while the lowest value of iron was $(100 \mathrm{mg}$ fe $/ 100 \mathrm{~g}$ ) for Giza 370 . The results are in agreement with that reported by(Chung, et al. , 2008).In addition, Dilis and Trichopoulou (2009) reported that, Legumes are generally characterized by its high mineral levels, a feature that depends on the species, the agronomic cultivar and certain characteristics of the soil where its grow.

Total Phenolics Content, Antioxidant activity and folate contents of different lentil varieties:

Legumes contain several antioxidant compounds such as vitamins $C$ and $E$, phenolic compounds and reduced glutathione (Fernandez-Orozc et al., 2009), which are considered to be natural antioxidants, representing an important group of bioactive compounds in foods, and may prevent the development of many diseases. Phenolic compounds do not only effectively prevent oxidation in foods; they also act as protective factors against oxidative damage in the human body. The antioxidant activity of phenolics is related to their chemical structure (Lopez-Amoros et al., 2006). Total phenols extracted from different lentil seed varieties were determined and the results are recorded in Table (3). lentil variety Giza 51 contained the highest content of total phenols which was 720 mg GAE $/ 100 \mathrm{~g}$ followed by lentil variety Sinai 1 which recorded 710 mg GAE /100g, while the lowest value of total phenols was $625 \mathrm{mg} \mathrm{GAE} / 100 \mathrm{~g}$ for lentil variety Giza 29. The difference might be attributed to the genotype of lentils. The obtained results were in same trend with (Amarowicz et al., 2009; Dilis and Trichopoulou 2009; Silva-Cristobal et al., 2010; Zou et al., 2011 ; Gharachorloo et al., 2012 and Rathod, and Annapure 2016).

Table (3): Total Phenols Contents (mg GAE/100 g), DPPH (\%) radical scavenging activity and folate Contents $(\mu \mathrm{g} / 100 \mathrm{~g})$ of different lentil varieties (on dry weight basis):

\begin{tabular}{|c|c|c|c|}
\hline \hline Varieties & TPC(mg GAE /100 g) & DPPH\% & folate $(\mu \mathrm{g} / 100 \mathrm{~g})$ \\
\hline \hline Giza 9 & $700.20 \mathrm{c}$ & $61.22 \mathrm{c}$ & $196 \mathrm{a}$ \\
\hline Giza 29 & $625.33 \mathrm{e}$ & $60.11 \mathrm{~d}$ & $184 \mathrm{~d}$ \\
\hline Giza 51 & $720.50 \mathrm{a}$ & $63.50 \mathrm{a}$ & $189 \mathrm{c}$ \\
\hline Giza 370 & $650.73 \mathrm{~d}$ & $60.65 \mathrm{~d}$ & $186 \mathrm{~d}$ \\
\hline Sinai 1 & $710.55 \mathrm{~b}$ & $62.42 \mathrm{~b}$ & $193 \mathrm{~b}$ \\
\hline
\end{tabular}

* Each value is an average of three determinations.

+ Values followed by the same letter in Column are not significantly different at $P \leq 0.05$

TPC : Total polyphenols content(mg galaic acid $/ 100 \mathrm{~g}$ )

Antioxidant activity ( DPPH\% ) 
The results were shown in Table (3), all sample extracts possessed good DPPH radical scavenging activity. lentil variety Giza 51 presented highest DPPH scavenging activity (63.50\%), followed by Sinai 1 (62.42\%), Giza 9 (61.22\%), Giza 370 (60.65\%), and finally by Giza 29 (60.11\%). Our results were in agreement with. (Amarowicz et al., 2009 ; Zou et al. 2011 and Gharachorloo, et al., 2012). In addation, Atienza et al. (1999) found that, legumes contain, beside phenolics, other bioactive compounds such as vitamins and carotenoids in different concentrations that can also affect the antioxidant activity of the samples. These compounds may exert a synergetic effect with phenolic compounds, which could be the reason for the observed differences in the antioxidant activity. It is also clear from the same Table that, Giza 9 contain the highest content of folate which was $(196.0 \mu \mathrm{g} / 100 \mathrm{~g})$ followed by Sinai 1 which recorded $(193.0 \mu \mathrm{g} / 100 \mathrm{~g})$ while the lowest value of folate was $(184.0 \mu \mathrm{g} / 100 \mathrm{~g})$ for Giza 29. These results are in the same trend of those reported by (Messina . 1999 and Chung, et al., 2008). They reported that, lentil are an excellent source of folate, which in addition to being an essential nutrient is thought to reduce the risk of neural tube defects. One serving of beans provides more than half of the current RDA folate .

\section{Antinutritional factors content in lentil seeds:}

Antinutritional factors such as phytic acid, trypsin inhibitors and tannins, which are present in lentil was considered undesirable for obstructing the bioavailability of minerals and they compromise the protein digestibility, harming the nutritional value of this food (Rathod, and Annapure 2016). Phytic acid, tannins content and trypsin inhibitors activity were determined in five lentil seed varieties and results are recorded in Table (4). The phytic acid, content of different lentil seed varieties were ranged from (0.49 to $0.56 \%)$.
On the other hand, lentil seed Giza 9 contains the highest content of tannins, which was $0.70 \%$ followed by lentil seeds Giza 370 which recorded (0.69\%) while the lowest value of tannins was $(0.64 \%)$ for lentil seeds Sinai 1 . Results also in the same Table indicate that, trypsin inhibitors activity of different lentil seed varieties were ranged from 2.82 (IU/mg dry mater) for Giza 29 to 3.12 (IU/mg dry mater) for Giza 9. In addition, no significant differences between the different studied types of lentil seed varieties for their trypsin inhibitors activity. These results are in line with those (Ghavidel and Prakash 2007; Dilis and Trichopoulou 2009 and Rathod and Annapure 2016) .

\section{Cooking quality of different lentil seed varieties (on dry weight basis):}

The cooking quality of five lentil seed varieties were determined and the results are recorded in Table (5). The values of Hydration coefficient of seeds before cooking (H.C.B.) for different lentil seed varieties were ranged from $116.60 \%$ for Giza 29 to $129.70 \%$ for Giza 370 . Same results were found by Selim (2000). Who reported that, high capacity to absorb water indicate good seed quality.

The percentage amount of water uptake by cooked seeds as represented by Hydration coefficient after cooking (H.C.A.) ranged from $106.70 \%$ for Giza 29 to $118.80 \%$ for Sinai 1. However, lentil variety Giza 9 contain the highest content of cookebility \% which was $(96.50 \%)$ followed by lentil variety Sinai 1 which recorded $(91.70 \%)$ while the lowest value of cookebility \% was $(88.40 \%)$ for lentil variety Giza 29 . These results are in the same trend of those reported by (Ezzat, Zakia, et al., 2005 snd Selim, 2000 ). 
Table (4): Phytic acid (\%), tannins content (\%) and trypsin inhibitors content (IU/mg dry mater) of different lentil seed varieties (on dry weight basis).

\begin{tabular}{|l|c|c|c|}
\hline \hline \multicolumn{1}{|c|}{ Varieties } & Phytic acid (\%) & Tannins (\%) & $\begin{array}{l}\text { Trypsin inhibitor } \\
\text { (IU/mg dry mater) }\end{array}$ \\
\hline \hline Giza 9 & $0.53 \mathrm{ab}$ & $0.70 \mathrm{a}$ & $3.12 \mathrm{a}$ \\
\hline Giza 29 & $0.49 \mathrm{~b}$ & $0.67 \mathrm{a}$ & $2.82 \mathrm{a}$ \\
\hline Giza 51 & $0.55 \mathrm{a}$ & $0.65 \mathrm{ab}$ & $2.96 \mathrm{a}$ \\
\hline Giza 370 & $0.50 \mathrm{~b}$ & $0.69 \mathrm{a}$ & $2.90 \mathrm{a}$ \\
\hline Sinai 1 & $0.56 \mathrm{a}$ & $0.64 \mathrm{~b}$ & $3.03 \mathrm{a}$ \\
\hline
\end{tabular}

* Each value is an average of three determinations.

+ Values followed by the same letter in Column are not significantly different at $P \leq 0$.

Table (5): Cooking quality of different lentil seed varieties .

\begin{tabular}{|l|c|c|c|c|}
\hline \hline \multicolumn{1}{|c|}{ Varieties } & (H.C.B.) & (H.C.A.) & T.S.S. \% & (coc.\%) \\
\hline \hline Giza 9 & $120.40 \mathrm{c}$ & $110.50 \mathrm{~b}$ & $1.50 \mathrm{~b}$ & $96.50 \mathrm{a}$ \\
\hline Giza 29 & $116.60 \mathrm{~d}$ & $106.70 \mathrm{c}$ & $1.14 \mathrm{c}$ & $88.40 \mathrm{c}$ \\
\hline Giza 51 & $123.50 \mathrm{~b}$ & $110.00 \mathrm{~b}$ & $1.97 \mathrm{a}$ & $89.30 \mathrm{c}$ \\
\hline Giza 370 & $129.70 \mathrm{a}$ & $108.40 \mathrm{C}$ & $0.80 \mathrm{~d}$ & $89.50 \mathrm{c}$ \\
\hline Sinai 1 & $117.50 \mathrm{~d}$ & $118.80 \mathrm{a}$ & $1.16 \mathrm{c}$ & $91.70 \mathrm{~b}$ \\
\hline
\end{tabular}

* Each value is an average of three determinations.

+ Values followed by the same letter in Column are not significantly different at $P \leq 0.05$

Hydration coefficient after cooking (H.C.A.)

Hydration coefficient before cooking (H.C.B.)

cookebility (coc.\%)

For the total soluble solids (T.S.S. \%) data in 5 table clearly showed significant variation among the tested samples. Giza 51 gave the highest value of T.S.S., 1.97, while Giza 370 recorded the lowest value of T.S.S., 0.97 . (Ezzat, Zakia, et al., 2005 snd Selim, 2000).

\section{Conclusion:}

From the obtained results, it can be concluded that: lentil variety Giza 51 contain the highest content of crud protein , minerals , total Phenolics content and antioxidant activity followed by variety Sinai 1 furthermore, Giza $\mathbf{3 7 0}$ contain the highest content of iron and potassium on the other hand, Giza 9 variety contain the highest content of folate and fat .Based on the above, it is recommended to use lentil seeds as a source of minerals, proteins and antioxidants,

\section{REFERENCES}

A.O.A.C., Association of Official Analytical Chemists (2005). Official Methods of Analysis of the Association of Official Analytical Chemists. 18th Ed. Washington, DC, USA,

Alonso, R., E. Aguirre and F. Marzo (2000). Effects of extrusion and traditional processing methods on antinutrients and in vitro digestibility of protein and starch in faba and kidney beans. Food Chemistry, 68, 159 -165.

Amarowicz, R., I. Estrella, T. Hernández, M. Dueñas, A. Troszyńska, A. Kosińska and B.R. Pegg (2009). Antioxidant Activity of a Red Lentil Extract and Its Fractions. Int. J. Mol. Sci., 10, 55135527.

Atienza, J., M. Sanz, A. Herguedas, J.A. Alejos and J.J. Jimenez (1999). Betacarotene alpha-tocoferol and gamma- 
tocoferol contents in dry legumes. Influence of cooking. Food Sci. Tech. Int. 4:437-441.

Barbana, C. and J. I. Boye (2011). Angiotensin l-converting enzyme inhibitory properties of lentil protein hydrolysates: determination of the kinetics of inhibition. Food Chemistry, 127, 94-101.

Chung, H. J., Q. Liu, R. Hoover, T. D. Warkentin and A. Vandenberg (2008). In vitro starch digestibility, expected glycemic index, and thermal and pasting properties of flours from pea, lentil and chickpea cultivars. Food Chemistry, 111(2), 316-321.

Dilis, V. and A. Trichopoulou (2009). Nutritional and health properties of pulses . Mediterr J. Nutr. Metab , 1:149157

Doblado, R., J. Frias and C. Vidal-Valverde (2007). Changes in vitamin $C$ content and antioxidant capacity of raw and germinated cowpea (Vigna sinensis var. carilla) seeds induced by high pressure treatment. Food Chem. 101:918-923.

Eyaru, R ., A. K. Shrestha and J. Arcot (2009). Effect of various processing techniques on digestibility of starch in Red kidney bean (Phaseolus vulgaris) and two varieties of peas (Pisum sativum). Food Research International, 42(8), 956-962.

Ezzat, Zakia, M., F. Ashmowy and Somaya M. Morsy (2000). Evaluation of some Lentil for earliness . yield components and seed quality Egypt . J. Agric. Res., 83( 1 ).151-165.

Fernandez-Orozc, R., J. Frias, H. Zielenski, R. Munoz, K. Piskula, H. Kozlowska and C. Vidal-Valverde (2009). Evaluation of bioprocesses to improve the antioxidant properties of chickpeas. LWT - Food Sci. Technol. 42:885-892.

Ford, R., R.J. Redden, M.M. Materne and P.W.J. Taylor (2007). "Genome mapping and molecular breeding in lentil: Lentil. In: Kole, C. (Ed.), Genome
Mapping and Molecular Breeding. Pulse, Sugar and Starch Crops" Heidelberg, Berlin, New York, Tokyo: Springer 3, 91-108.

Fruehbeck, G., R. Alonso, F. Marzo and S. Santidriaan (1995). A modified method for indirect quantitative analysis of phytate in foodstuffs. Analytial Biochemistry, 72, 248-254.

Gharachorloo, M., B.G. Tarzi1, M. Baharinia and A.H. Hemaci (2012). Antioxidant activity and phenolic content of germinated lentil (Lens culinaris). J. of Medicinal Plants Res., 6 (30), $4562-4566$.

Ghavidel, R. A. and J. Prakash (2007). The impact of germination and dehulling on nutrients, antinutrients, in vitro iron and calcium bioavailability and in- vitro starch and protein digestibility of some legume seed. Food Sci. and Tech., 40, 1292-1299.

Gutfinger, T. (1981). Polyphenols in olive oils. J.Amer. Oil. Chem. Soc.58: 966.

Kakade, M. L., J. L. Rackis, J. E. McGhee and G. Puski (1974). Determination of trypsin inhibitor activity of soy bean products: A collaborative analysis of an improved procedure. Cereal Chemistry, 51, 376-382.

Karaca, A. C., M. T. Nickerson and N. H. Low (2011). Lentil and chickpea protein stabilized emulsions: optimization of emulsion formulation. J. of Agri., and Food Chemi., 59 (24), 13203-13211.

Leterme, P. and L.C. Munoz (2002). Factors influencing pulse consumption in Latin America. British Journal of Nutrition, 88(Suppl. 3), 251S-254S.

Lopez-Amoros, M.L., T. Hernrndez and I. Estrella (2006). Effect of germination on legume phenolic compounds and their antioxidant activity. J. Food Compost. Anal. 19:277-283.

Ma, Z. Boye, J. I., B.K. Simpson, S.O. Prasher, D. Monpetit and L.D. Malcolmson (2011) . Thermal processing : effects on the functional 
properties and microstructure of lentil, chickpea, and pea flours. Food Res. International, 44 , 2534-2544.

Messina, M. J. (1999). Legumes and soybeans: overview of their nutritional profiles and health effects. Am. J. Clin. Nutr., 70 (I):4395-505.

Murphy, J. and J.P. Riley (1962). A modified single solution method for determination of phosphate in natural waters, Anal. Chem. Acta., 27: 31-36.

National Academies of Sciences, Institute of Medicine (2001). Fruits and vegetables yield less vitamin $A$ than previously thought; upper limits set for daily intake of vitamin $A$ and nine other nutrients, Press Release Jan. 9.

Pearson, D. (1976). The Chemical Analysis of Foods, 7th Ed. Churchill, London, U.K.

Price, M. L., S. Van Scoyoc and I.G. Buter (1978). A critical evaluation of the vanillin reaction as an assay for in sorghum grain. J. Agric. Food Chem. 26: 1218-1219.

Rathod, R. P. and U.S. Annapure (2016). Effect of extrusion process on antinutritional factors and protein and starch digestibility of lentil splits. Food Sci. and Tech., 66 ,114-123.

Roy, F., J. I. Boye and B. K. Simpson (2010). Bioactive proteins and peptides in pulse crops: Pea, chickpea and lentil. Food Research International, 43(2): 432-442

Selim, T. A. A. (2000). Genotype and environmental effects on seed yield, yield components and seed qyality in lentil. Msc.tThesis, Fac. Agric., ALAzhar Univ., Egypt.

Silva-Cristobal, L., P. Osorio-Díaz, J. Tovar and L. A. Bello-Pérez (2010). Chemical composition, carbohydrate digestibility, and antioxidant capacity of cooked black bean, chickpea, and lentil Mexican varieties. J. of Food, 8:1, 7-14.

Soler-Rivas, C., J.C. Espi'n and H.J. Wichers (2000). An easy and fast test to compare total free radical scavenger capacity of foodstuffs. Phytochemical Analysis, 11, 330-338.

Steel, R.G. and J.H. Torrie (1980). Principles and Procedures of Statistics. McGraw-Hill (Publ.). New York, NY.

Wang, N. and J.K. Daun (2006). Effects of variety and crude protein content on nutrients and anti-nutrients in lentils (Lens culinaris). Food Chem. 95: 493502.

$\mathrm{Xu}$, B.J. and S.K.C. Chang (2007). Comparative analysis of phenolic composition, antioxidant capacity, and color of cool season legumes and other selected food legumes. J Food Sci. 2007; 72: 167-177.

Zohary, D. and M. Hopf (2000). "Domestication of plants in the old world (3rd ed.)" New York, NY: Oxford University Press.

Zou, Y., S. K. Chang, Y. Gu and S. Y. Qian (2011). Antioxidant activity and phenolic compositions of lentil (Lens culinaris var. Morton) extract and its fractions. J. Agric, Food Chem., 23 (6): 2268-2276. 
المركبات الفيتوكيمائية والنشاط المضاد للاكسدة لبعض اصناف العدس المنزرعة فى مصر. - مص

\author{
علدى سمير عبد الستار سعد
}

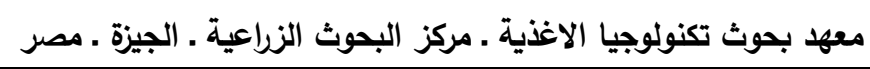

الملخص العبى

اجريت هذه الاراسة بهدف مقارنة و تقييم بعض اصناف العدس التي تزرع في مصر لتحديد الأصناف ذات الجودة

اظهرت النتائج ان العدس صنف جيزة 51 تحتوي على اعلى نسبة من البروتينات التي بلغت (25.55\%) يليها لصنف سيناء 1 والتي سجلت (24.83٪) بينما كانت اقل قيمة للبروتينات (23.10٪) للعدس صنف جيزة 29 .وجد ان البوتاسيوم

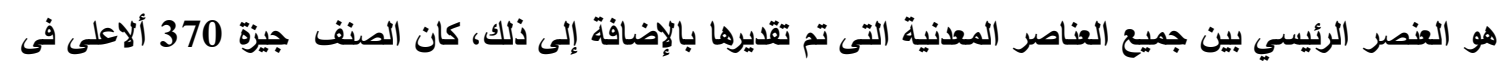

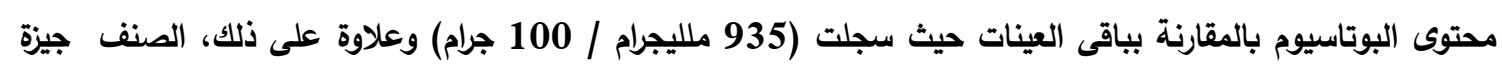
370 يحتوى على أعلى كمبة من الحديد حيث كانت (11.30 ملليجرام / 100 جرام).

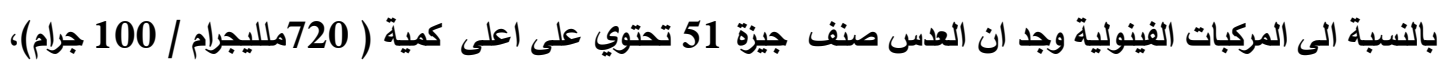

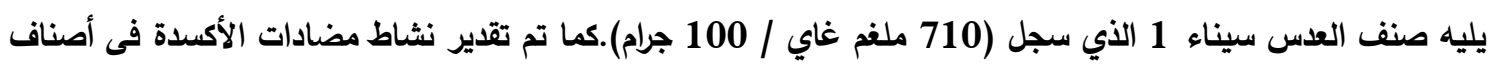

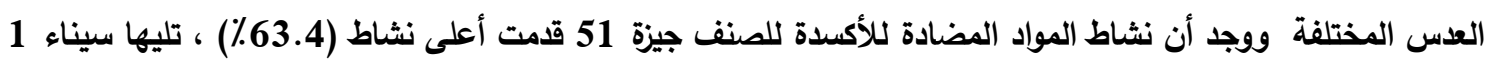
(62.42\%)، في حين أن الصنف جيزة 9 يحتوي على أعلى كمية من حامض الفوليك الذي كان (196.0 ميكروجرام / 100 جرام) يليها سيناء 1 التي سجلت (193.0 ميكروجرام / 100جرام ). من ناحية أخرى، تراوحت نسبة حامض الفئ الفيتيك

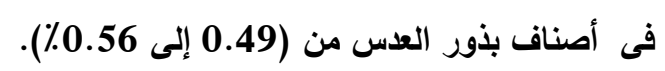

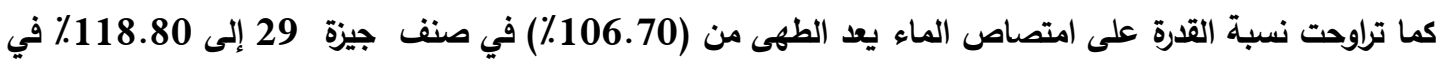

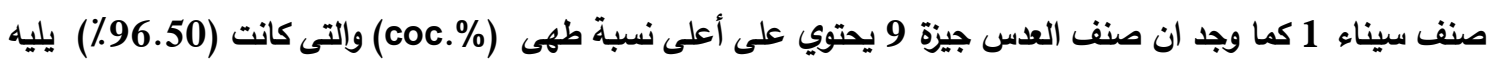
صنف العدس سيناء 1 والذي سجل (91.70٪). التوصيا ت:

مما سبق نجد ان العد صنف جيزه 51يحتوى على اعلى كميه من البروتين والمركبات الفينوليه والنشاط المضاد للاكسده يليه صنف سخا 1 .علاوه على ذلك نجد ان صنف جيزه 370 يحتوى على اعلى كميه من الحديد والبوتاسيوم فى إنى حين ان صنف جيزه 9 يحتوى على اعلى كميه من الفولات وإلدهن ولذلك يوصى باستخدام بذور الاصناف السابقه كمصدر للمعادن و البروتينات والمواد المضادة للاكسدة .

أسماء السادة المحكمين

$$
\begin{aligned}
& \text { أ.د/ سحر رمضان عبدالهـــادى معهد بحوث القطن - سخا - مركز البحوث الزراعية } \\
& \text { أ.د/ السيد حلمى عبدالسلام رحمه كلية الزراعة - جامعة المنوفية }
\end{aligned}
$$


Phytochemical compounds and antioxidant activity of some lentil ................ 